DOI 10.38129/ Ann.Yur.Ist.2019.3.3.4.68

УДК 001.18:008.2:316.77(007.51:001.51)

\title{
ГЛОБАЛЬНОСИСТЕМНІ ВИМІРИ ВСЕСВІТНЬО-ІСТОРИЧНОГО ПРОЦЕСУ: ШЛЯХ ВІД ІМПЕРСЬКОГО ДО ДЕМОКРАТИЧНОГО MODUS VIVENDI
}

(теоретично-концептуальний і методологічний аспекти)

ОЛЕКСІЙ СКАЛЕНКО (Київ, Україна)*

«Мірило усіх речей - людина»

(Протагор)

«Хозяйство есть знание в действии, а знание есть хозяйство в идее»

(С. М. Булгаков)

\section{Передмова}

Очевидні та практично виявлені реалії і тенденції розвитку сучасного світу об'єктивно надають нам можливість глибинно дослідити не тільки всесвітні трансформації, але й в котрий раз зафіксувати кризовий стан майже в усіх сферах життя на нашій планеті. Найактуальніший напрям наукового пошуку - це фундаментально-науково, тобто у всезагальносистемному вимірі розглянути ситуацію, яка склалася не тільки в усьому планетарному просторі, а й глобально, тобто з урахуванням необхідних природних об'єктивних закономірностей речовинно-енергетичних, гуманітарних, суспільно-політичних, технологічно-економічних процесів, $i$ загалом, самої сутності изивілізаційного поступу.

Особливо гостру актуальність сьогодні набули проблеми адекватної теоретико-методологічної концептуалізації в сфері геополітики та геоекономіки. Гострота цих проблем полягає насамперед в тому, що тенденція розвитку світу реально виявилась в практично невідворотних процесах так званої глобалізації и надінтенсивної інформатизації. Цілком закономірно, що в нових умовах перестають бути повністю ефективними методи власне державницього управління соціальними процесами та міжнародними відносинами. Ось чому дуже поширились явища системної дезінтеграції, як конкретно поміж людьми, так і геополітично - в міждержавній комунікації. Наше конкретне завдання у даній роботі викрити глибинні витоки виявлених феноменів і науково усвідомити сутність об'єктивного закономірного переходу реального буття суспільств 
різного рівня віd фактичного імперського до демократичного тоdus vivendi.

Передусім зафіксуємо, що використовуваний автором в цій роботі термін «глобальносистемність» означає адекватну відображеність та місце об'єкта нашого дослідження у всезагальній світовій структурі на природно $i$ соціально закономірному плані. Нами визначено, що цю структуру складають: людина (людство) як суб'єкт активності в соиіальній формі світового розвитку та речовинно-енергетична сфера як єдиний об'єкт $i$ ресурсна першооснова (екосфера) в глобальній системі всеохоплюючої взаємодії у всесвітньоісторичному вимірі, тобто з самого початку існування і активнотворчої діяльності homo sapiens як homo socialis.

Таким чином, об'єктивно закономірна глобальність власне Всесвітнъого проиесу по-суті, зобов'язує дослідника враховувати в усіх системах активнотворчої діяльності сутність людини та ї природно-екосорерний потенціал. Такий, фактично глобалізуючий підхід демонстрували вже навіть класики «марксизму». Однак в реальності все ж виявилось, що hото sapiens й homo socialis сприймає світ не тільки безпосереднъо, а й глобально опосередковано - трансінформаційно, тобто вже з використанням ресурсу інформаційних знань як ідеального абстрактного, але глобально єдиного иільового орієнтира щодо ефрективності та всебічної безпечної діяльності в об'єктивно непорушній сфері законів природи. Тут також доречно буде привести думку Вельми Войовничого марксиста й ортодокса-матеріаліста, який сам собі суперечить: «від живого споглядання - до абстрактного мислення, а від нього - до практики».

Попри багатозначність сприйняття та розуміння, термін «криза», по суті, в контексті нашого дослідження, розглядається як наближення процесу до апогею $b$ еволюиійному переході на новий етап світового розвитку. Отже, будучи наближеним до певного екстремуму, цей перехід закономірно Виявляється природним, хоч і важким для людей за усіма параметрами. I тому його критичнии стан також слід визначити в якості еволюиійно закономірного. I, мабуть, в попередньому плані доцільним буде вважати, що саме розуміння позитивної сутності цъого переходу стане першим кроком в напрямі науково-системного подолання супутніх кризових ситуацій, включно проблеми відходу від імперативного способу управління соціуммами.

Термін «імперативниӥ», латиною imperativus, означає «владний», а однокореневе «ітрегіuт» 3 латини - це імперія як форма здійснення володарювання. Тобто, терміни імперський й імперативний вживаються майже однозначно, з єдиною різницею в тому, що імперський - це назва методу управління спільнотами в єдиному інтегрованому центрі верховної влади. 
Сутність ключового терміну наших студій («ци и $b$ iл $і$ з $а$ u, $і$ я») також $€$ неоднозначною. Часто цивілізацію дефініюють як синонім всесвітнъої культури, форми або рівня пї розвитку. А стосовно значення іншого ключового поняття - «трансінформаційна цुивілізація», - то тут мова повинна йти, власне, про функціонування за своєю сутністю та впливом глобальносистемного, пріоритетно стратегічного ідеально-інформаційцуного чинника в методологічно повних соціокультурних, політико-економічних $i$, зрештою, иивілізаційних системах.

Зрозуміло, що всебічно ефективна реалізація функцій кожної складової в кожній системі діяльності, а тим більше найвпливовіших чинників в глобальній структурі людської діяльності, та ще конкретніше - в об'єктивно існуючому середовищі, принципово потребує вidnoвidної компетенції, тобто відповідних знань, але вже в глобально-системному вимірі.

Ми стверджуємо, що власне обсяг накопиченого якісного інформаційного практичного досвіду, усвідомленого на даному етапі еволюції - це і є результативно ефективний шлях поступу людства до більш досконалого управління своїм життям, але лише в межах об'єктивно непорушних законів природи. I першочергово це стосується переходу, а вірніше - закономірного поступу соціально еволюиійної форми управління своїм життам - від «імперського до демократичного modus vivendi». Саме цією розробкою ми представляємо інноваційну своєрідну «дорожню карту» глобально-системного виміру як феноменологію ідеального інформаційного ресурсу в усіх без виключення системах ююдської діяльності, передусім в процесах самоуправління. Автор щиро сподівається, що всі описані методологеми стануть більш зрозумілим і придатними до акцептування науковим співтовариством з матеріалів, коротко викладених у наступних положеннях пропонованої концептуальної розробки.

\section{Історичний феномен трансінформаційної глобалізації світу XX-XXI ст.}

\section{Ми можемо стільки, скільки знаємо (Френсіс Бекон)}

В процесі тривалих цілеспрямованих досліджень нам стало зрозуміло, що «загадковии саморозпад» наддержавних структур усіх часів є переконливим свідченням тектонічних зрушень у світовому житті саме за рахунок суттєвого, імперативно й невідворотно посиленого впливу вказаних глобально-системно найбільщ глибинних чинників в сфері людської діяльності. I мова тут піде саме про пріоритетні, найвпливовіші чинники сучасного розвитку в їх взаємозв'язках та механізмах діалектичної взаємодії. 
Зафіксуємо, що саме життя сьогодні не тільки очевидно практичне, але й концептуально та методологічно виявило по-суті глобальносистемні важелі управління світовими політичними, соціокультурними та економічними проиесами. Попереднім чином також сформулюємо, що в якості таких важелів нами визначені соціально й системно рушійний гуманітарно-людський чинник (ГЛЧ) та революиійний вимір інновації - високі інформаційні технологіі (BIT). В умовах відчутного зменшення традиційних ресурсів розвитку та погіршення екології: перший важіль - ие людина як діючий суб'єкт, другий важіль - ие високі науково й духовно-інформаційно насичені, гуманітарносочіально та економічно-екологічно спрямовані технології в усіх сорерах життя [2].

Враховуючи конкретну, а саме службову роль науки, продовжимо на прикладі, що сучасна Україна не тільки відродилась як самостійна держава, а й об'єктивно опинилась тепер у принципово зміненому світі. При цьому нам вже цілком зрозуміло, що начебто несподівана, але доконечно впливова подія специфрічного «саморозвалу» «імперії» СРСР - це також явище об'єктивного всесвітнъо-історичного виміру. Принагідно нагадаємо, що нашими цілеспрямованими глобальносистемними дослідженнями встановлено, що ця подія виявивилась наслідком надмірного спотворення «табір-всесоюзного» психоінформаційного простору [2,3]. Відтак, ми врахували цей системний фактор при вивченні реалій нашого життя на поточному етапі світового цивілізаційного розвитку як знакового щодо закономірно кінцевого переходу деяких сучасних суспільств від імперського до демократичного стану. Особливо це стосується країн, держав і спільнот 3 ортодоксально проімперською матеріалістичною ідеологією.

Проте, зміцнення сутності державності наразі є системно заскладним для України і вирішальним чином сьогодні залежить від існуючого світопорядку, реалій і тенденцій глобального розвитку, а також реального стану нашого господарства 3 дещо загальмованим менталітетом внутрішнього духовного та інтелектуального творчого потенціалу, від усіх ресурсів. Адже тільки ці чинники зможуть обгрунтувати цілі й реальні програми відродження держави.

Наступне. Загальний стан сучасного життя людства дивує не тільки своїми однобічними позитивами, а й, відверто кажучи, катастрофічними негативами. Уся наша планета вражена небезпечною екологічною кризою. Постають перманентно присутні соціально-економічні кризи, ідеологовоєнізовані політичні конфлікти, ускладнені ефектами під назвою «кібернетичні», «інтелектуальні», «інформаиійні» чи навіть «психоінформаційні» війни. Одночасно, з відчутно планетарною напругою 
раз за разом виникає розголос про апокаліпсис чи кінець світу. Усвідомлюючи стан, що наближає людство до надзвичайно небезпечної глобально-системної кризи, ми активізували свої дослідження в напрямі наукового усвідомлення глибинних сутнісних причин такого стану i пошуку методологічно адекватних та практично обгрунтованих шляхів ефективнішого шляху світового розвитку.

Враховуючи, що всесвітня історична думка видатних мислителів нашої планети постійно розвивалась навколо глобальної проблематики покращення людського життя, ми 3 великою вдячністю сприймаємо результати їхніх роздумів щодо подолання шляху життєво кризових ситуацій. В першу чергу звернемо увагу на відповідні досягнення наших вчених співвітчизників, і особливо на наукові праці видатного глобаліста сучасності, першого президента Української академії наук, В. I. Вернадського, який цивілізаційно наголошує: «упровадженням символів, літер $і$ чисел людство осягнуло ијилічність та інтенсивність впливу природних явищ, на своє життя, навчилося користуватися изми знаннями та передавати їх прийдешнім поколінням, фактично започатковуючи ицм свою ицивілізаційну iсторію». Додамо, що в сьогоденній новітній історії, і також, за мудрим визначенням геніального фундатора ноосферного мислення Володимира Вернадського, «науковий світогляд є творінням людського духу, поряд 3 релігієзнавством, мистецтвом, особистою та соціальною філософською думкою». I там же: «у ноосфері визначальним і вирішальним чинником є духовне життя власне людської особистості у ї̈ спеицфрічному виявленні». А також ще одна глобальна думка-передбачення автора вчення про ноосферу: «розповсюдження наукового знання та освіти є основним чинником інтеграчзї людства $b$ єдине цүіле». I саме ці, за нашим визначенням, глобальносистемні думки про шлях переходу вid, по-суті імперативного до демократичноноосферного способу суспільного політекономічного самоуправління, складають найцінніший скарб для людей сучасного, вже специфічно глобалізованого світу [1-3].

Якщо не тільки прагматично, а й по-сучасному науково, тобто глобально як загальносистемно, підходити до проблем, так чи інакше пов' язаних зі станом ициілізації сbітового простору, то насамперед зафріксуємо реальну картину соціально опосередкованого світу взагалі. І цю реальність треба розглядати як таку, яку, починаючи 3 доісторичних часів, сучасне багатомільйонне людство зі своїми потребами принципово не може змінити, а тим більще відмінити найглибинніші основи свого існування. Отже, в глобальному історичному плані доречно нагадаємо: найглибшими підвалинами загальноцивілізаційного поступу завжди були, є, завжди будуть 
матеріально-енергетична першооснова та науково-інформаційний базис соціально-культурної і технологічно-економічної діяльності в природному, об'єктивно існуючому світовому середовищі.

Ще раз нагадаємо: тут ми повинні добре усвідомити, що людська діяльність як цілеспрямований процес глобальносистемно потребує i фізичних речовинно-енергетичних, ӥ ідеальних, тобто абстрактних ресурсів, які закономірним, реальним чином формуються історично процесуально, відтак транс-психо-інформаційно, отже шляхом пізнання об'єктивно існуючого речовинно-енергетичного середовища. Тут згадаємо також, що результатом суб'єкт-об'єктного пізнання є не тільки речовинно-енергетичний продукт, а й так званий «супутніӣ», ідеальний інформаційно-знаннєвий ресурс, який споконвіку, в історичному плані послуговує людству деяким специфічним «мостоукладачем» на шляху його життєвого забезпечення й системного само-вдосконалення, й відтак, в прогресотворчих изивілізаційних проиеесах. Отже, ще раз підкреслимо, що будучи невід'ємною, природно єдиною частиною цілісного, об'єктивно існуючого середовища, людина сприймає світ як безпосередньо, тобто як все існуюче в стихійному самобутті, так і специфічно - ідеально-інформаційно опосередковано. I саме в цьому контексті закономірно треба закцентувати єдність матеріального й ideального.

До речі, занадто проімперські твердження матеріалістів про те, що все почалося i залежить лише від матерії, хоч i були глибоко фундаменталістськими але реально виявились «ієрархічно» помилковими щодо суб'єкт-об'єктних відносин взагалі. Адже в системах соціальноекономічної праці, як процесах принципово цілеспрямованих, власне мета діялності сутнісно формується лище на основі ідеального інформаційного ресурсу, і саме тому вона об'єктивно закономірно виступає ієрархічно первинною, отже, пріоритетно вирішальною відносно ефективності та безпеки розвитку. Як наслідок такої помилки можна вказати на парадокс «наявного товарного дефіциту» в «прокомуністичних суспільствах» та на дезінформаціиині підстави начебто «загадкового саморозвалу» цілком антиідеалістичної, всесоюзно-табірної, а фактично імперської наддержави, яка безоглядно сповідувала саме так звану матеріалістичну ідеологію.

Г л о б а л ь н о с и с т е м н о аналізуючи сучасний стан розвитку світової спільноти, в першу чергу розвинених країн, i, зокрема країн, що сьогодні інтенсивно розвиваються (для прикладу, індійського та китайського суспільств), особливу увагу мусимо звернути на дивовижний, високо піднесений в них поступ інтелектуальної еліти в сфері комп'ютерного програмування та інноватизації в сфері інформаційних технологій. 3 точки зору розробленої автором глобальносистемної 
трансінформаційної методології та глобалістично-цивілізаційного підходу, такий рівень уваги до проблем інформатизації свого національного життя свідчить не тільки про психоінтелектуальну рушійну силу науковотехнологічної сорери, а й, головним чином, про відродження культурної давнини усіх народів світу, тобто суть філософсько-пізнавального потениіалу найвидатніших провідників духовності, які глобально систематизували вчення про суспільний розвиток та поступ людини як активнотворчої особистості.

Тут також зауважимо, що життєво й цивілізаційно глобалізучий ідеально-інформаційний ресурс в сучасному індустріально розвиненому світі використовується вже не так як, наприклад, в доіндустріальному суспільствi, а незрівнянно інтенсивніше й динамічніше, за рахунок новітніх інформаційно-комунікаційних технологій (IKT). Інформаційні знання, як об'єктивно фундаментальний ресурс соціально-економічного поступу, поширюються практично з електронною, радіо- та фотонною швидкістю в планетарному, і навіть космічному масштабах. Мова тут, звичайно, йде не тільки про удосконалені інформаційно-комунікативні технологї, а саме про змістовну сутність та глобальне соціально-економічне значення фрномену інформачійних знань, про об'єктивно фундаментальний, космічний характер процесів всезагальної інформатизації світу з відповідною иоого глобалізацією. Це іє реальний поступ людства, починаючи від етапу, коли ююдство щуе не накопичило знань як інформачійного ресурсу для переходу на вищий етап розвитку, до більш ефективного демократичного modus vivendi $b$ глобальносистемному вимірі. Згадаймо, що ще древній Сократ передбачливо наголошував: «винахідницький геній народу є батьком усякого багатства». Новітня історія свідчить, що вже настав час усвідомити сутність демократизациї.

Якщо звертатись не просто до давнини, а взагалі до чудових досягнень всієї людської ицвілізації, то світова науково-творча спільнота сьогодні повинна пишатись велетенськими результатами думки євроатлантичних, близько-, середньо- та далекосхідних глобалістів усіх часів та народів. Зрозуміло, що то були минулі часи 3 власною історичною специфікою і наукова систематизація знань, відповідно, була іншою. Однак глобалізаційноциивілізаційний підхід до вивчення сучасних хвиль інорорматизації показуе глибину та вирішальний характер їхнього впливу на розвиток $і$ подальшу долю ююдства. Особливо акцентуємо увагу читача на епіграфі до цього розділу - «ми можемо стільки, скільки знаємо» (Френсіс Бекон).

3 цього приводу також згадаймо, що без ідеально-інформаційного ресурсу принципово не може бути сформована ніяка, за суттю також ідеальна мета 
усякої фізичної чи інтелелектуальної праці. Тобто ніяка система економічної та й, взагалі, усякої соціокультурної діяльності. Все це стало об'єктивно закономірною і практичною підставою для реального виявлення феноменів надінтенсивної інформатизацї світу ma відповідної глобалізацї світового господарства на новітнъому етапі изивілізаційного розвитку.

Також ствердимо тезу, що об'єктивно пріоритетною і найгострішою потребою сьогоденного світового, регіонального та національного розвитку $\epsilon$ пріоритетний розвиток сорери науки як головного виробника якісного інфрормаціиіно-знаннєвого ресурсу у тісному взаємозв'язку зі сорерами освіти $i$ якісної фахово-виробничої підготовки висококваліфрікованих, творчо спроможних mpудових кадрів. В першу чергу, це стосується розробки всебічної науково обгрунтованої, відповідної реаліям сьогодення методологічно-концептуальної інорормаціï.

Отже, проблема досягнення такої, можна сказати, ноосферо-спрямованої мети, насамперед включає в себе завдання розробки історично відповідної методології діяљності і розвитку, а також необхідності ретельної розробки теорії та конкретних концепцій сучасної соціокультурної, економічної й технологічно-виробничої діяльності на найбільш глибинних підвалинах, тобто на фундаментально змістовних глобальносистемних засадах. Актуально це проблеми новітньої історії й специфічно системної, по сучасному «гібридної», індустріалізації усього світу, особливо нашого національного життя. А головно - це змістовне усвідомлення людством об'єктивно необхідного, категоричного імперативу науково-духовного возз'єднання ююдства $з$ метою демократнично-синергетичного формування методології практичної та планомірної діяльості задля покращення modus vivendi b умовах існуючих реалій $i$ тендениій розвитку.

\section{Вузлові моменти глобальносистемного підходу щодо деімперіалізації соціально-економічного розвитку}

Взаємопов'язано, тобто глобально та системно, розглядаючи сьогоденні реалії світового розвитку ми ще раз відзначаємо: однією з найважливіших реалій безумовно є феномен глобалізації ююдського життя, здебільшого, як уже стало зовсім очевидно, на підставі так званої інформаціиіно-технологічної революиіи. Революційна висота новітніх інформаційних технологій цілком закономірно сформувала переважно технократичний погляд прагматиків і навіть науковців на сучасний розвиток, що свідчить про однобокість підходів до врахування та подолання проблем інтенсивної інорорматизації $і$ глобалізації світового господарського, та й усъого соијокультурного життя людства. 
Тривалий час всезагально й системно досліджуючи цю надскладну проблематику, ми саме таким глобальносистемним чином дійшли цілком закономірного висновку, що феномени інформатизації й глобалізації сутнісно, на глибинному фундаментальному рівні, взаємопов'язані й принципово, тобто на об'єктивному рівні нерозривні. Фундаментально-об'єктивний рівень цього зв'язку означає, що тут потрібно науково й системно усвідомити ієрархію причинно-наслідкових чинників при розгляді методологічно й праксеологічно повноцінних соціально-економічних процесів та структурно поставити феномен інформачійних знань - в якості чинника об'єктивного та реального орієнтування в системах ююдської діяльності - на функціонально відповідне, тобто на пріоритетне стратегічне місце в усіх сорерах розвитку.

Встановлено, що феномен інформащії, на відміну від класичних традиційних речовинно-енергетичних ресурсів розвитку, власне є сутнісно ідеальним суб'єктивно-об'єктивним (діалектичним) феноменом, тобто абстрактним чинником $i$ пріоритетним стратегічним гарантом трудового успіху, отже структурним, функціонально незамінним ресурсом в процесах організації праці, безпечного та ефективного управління соціальноекономічними, а також соціо-духовно-культурними або цивілізаційними системами. Однак, так званий проімперський modus vivendi продовжує домінувати в усіх недемократичних суспільствах, олігархічно зловживаючи ресурсом інформаційних знань в сфері політики, науки та освіти. «Мамоновського» типу можновладці вже доводять системи життя людей до стану гострої кризи, до рівня «дезінформаиійно-дезінтеграційного тодиs vivendi», 3 усіма його негативними наслідками щодо подолання проблеми покращення життя.

Інформаційні знання як умовно абстрактний, отже ідеальний продукт трудових, тобто суб'єкт-об'єктних відносин, є енергетично інертним, відтак, «несаморухомим» феноменом і тому необхідно в процесах його формування і зберігання, обробки та доцільного використання як ресурсу, керуватись дієвою силою компетентно сформованої психічної енергї людини як виняткової рушійної сили изих процесів. На відміну від природно, тобто стихійно саморухомих речовинно-енергетичних чинників в процесах розвитку, інфрормачійний ресурс є феноменально специфрічним за своєю сутністю та способом функціонування $b$ соиіально-економічних структурах, але виступає єдиним засобом цілепокладання і трудового системотворення, а також об'єктивно обгрунтованої орієнтації, а саме - орієнтації в процесах творчої інтелектуальної праці та управління цими системами на основі психічної енергії ююдей як єдиної доцільно рушійної сили, власне мікропроцесів ююдської життедіяльності. I саме цей факт є витоком імперативного modus vivendi. Але реальне життя показує, 
що соціально ефективне рішення може бути прийнято лише на вершині «піраміди», яка власне іє демократичною основою.

Відтак, викладені в усіх наших працях концептуальні положення, суворо кажучи, самі по собі мають глобалістичний вимір, тому що відображають, передусім, об'єктивну непохитність законів перебігу суто природних процесів й природну здатність ююдини пізнавати иі закони та формувати відповідну наукову системно-інформаційну картину світу, і зрештою, творчо-доцільно використовувати історично накопичуваний ресурс інформаційних знань для задоволення своїх духовних, фізіологічних й екологічних потреб. I саме в цьому полягає сенс переходу сbіту із імперського в демократичний стан.

Доволі динамічно актуалізовані тенденції політичного сьогодення демонструють вже надімперативний наступ так названих глобалізаиійних процесів. Відтак, якщо по-можливості адекватно розглядати найважливіші події у сучасному житті держав і народів, то без усякого сумніву потрібно це робити, передусім, з урахуванням чітко виявлених реалій і тенденцій світового й національного розвитку, але мабуть уже за відповідним до часу глобальним, вірніше - глобальносистемним, отже інноваційно изивілізаційним підходом.

Таким чином, беручи до уваги вищевказані імперативні фрактори сучасного розвитку i, зважаючи насамперед на динаміку подій XX та початку XXI століть, спробуємо науково усвідомити вплив найголовніших чинників на життєво найважливіші події цього часу не тільки в горизонтальному, але й у вертикальному зрізах, в останньому випадку глобально-системно. Зауважимо, що саме 3 цього моменту має ставати зрозумілою, своєрідна зміна «імперативів всесвітнього процесу» - від «лише проімперсъкого» способу самоуправління людсъкими спільнотами - до суспільно-політичного, об'єктивно синергетичного, як природничо закономірного, а отже і політологічно демократичного.

Також наголосимо, що природна здатність людини, як суб'єкта абстрактно пізнавати світ й історично накопичувати ідеальноінформаційні ресурси, надала йй можливість соціокультурного та активного творчого технологічно-економічного поступу випереджувальним й передбачувальним шляхами; еволюційно, i навіть революційно, а іноді навіть біфуркаційно, підвищувати ефективність своєї непростої діяльності, перманентно і комплексно системно удосконалювати управління саморозвитком.

Відтак:

I. Ідеально-абстрактне, тобто інформаційно-знаннєве опосередкування u̧ивілізаційного процесу надає людині можливість самопізнання не тільки як 
невід'ємної частини всесвіту, а й як творчої особистості та соціосинергетично-діючого суб'єкта в реальній сфері об'єктивно існуючого речовинно-енергетичного середовища. Отже, це геній імперативного волевиявлення людини.

II. Ідеальний інформаційний ресурс практично функціонує в соціально-економічній сфері як мірило реальності, тобто як глобально орієнтуючі, універсальні знання про світові процеси. Цей ресурс історично накопичується та без усяких обмежень може використовуватись в кожній системі оперативної і стратегічної діяльності. Тут ще раз звернемо увагу на те, що будучи єдиним і повноважним представником об' єктивно існуючого світу, саме таким закономірним чином інорормаційні знання $b$ єдності з волею людини імперативно стверджують свою пріоритетну стратегічну роль $i$ свіи глобально впливаючий статус в світовому й особистісному житті, отже і в загальному изивілізаційному процесі. Тобто, переважно імперативний характер організації суспільних дій людей на певному етапі еволюційного розвитку має свої об'єктивні підстави.

Доповнимо, що ідеальний інформаційно-знаннєвий ресурс своєю глобально впливаючою, можна навіть сказати, суперфункцією, надає чудову можливість homo sapiens / socialis теоретично експлікуватись саме в ідеальну сореру природно закономірних можливостей та активнотворчо здійснювати трансінформаційне моделювання і вибір варіантів практичної реалізації проектів, доцільних для вирішення соціально-культурних і технологічноекономічних потреб.

Але саме такий шлях вирішення проблем та забезпечення потреб із самовдосконаленням людського життя реально має глобально-системний buмір і цей шлях на усіх підставах можна і треба назвати всезагальноизиілізаційним. Принагідно наголошуємо, що глобально-системно поглиблюючи доконечний висновок даної тези, необхідно назвати визначену суперфункиію інформаційних знань глобально-прогресотворчою. А якщо все ж визнавати функції імперативного чинника в процесах ююдської життедіяльності необхідними, то ичю роль треба чітко віддати об'єктивно непорушним законам природи.

Відтак, якщо ми визначаємо ідеально-інформаиійний ресурс стратегічно пріоритетним в усій ієрархї̈ чинників ицивілізаційного ӥ економічного процесів, $i$ саме за глобально-системним виміром, то це практично означає, що власне усі сорери соціального життя закономірно потребують високоякісних, відповідних до своїх конкретних иілей, достовірних інформаційних знань. Гуманітарну сферу, наприклад, попри деяку легковажність сучасного суб'єкта щодо розуміння вирішального глобального впливу інформаційних знань на соціально-економічний 
розвиток, фактично треба вважати «альфою і омегою» ефективності активнотворчої праці і управління економічними системами. I це, насамперед, переконливо свідчить про глобально-системний статус ІНФОРМАЦІЇ в сфері людського життя не тільки на пріоритетному стратегічному рівні, а й в поточному плані оперативного управління діяльістю протягом методологічно й праксеологічно повного процесу досягнення трудового результату.

Як попередній висновок надаємо глобально-системну фрормулу історичного та сучасного ЦИВІЛІЗАЦІЙНОГО ПРОЦЕСУ: «об'єктивно існуючий матеріально-енергетичний світ >соиіум > науково-освітня сорера >інорормаційні, духовно збагачені знання >mворчий інтелект >інновації >високі технологіі >виробництво >морально й духовно правосвідоме $i$ матеріально удосконалене життя». Зрештою, це і виявиться результативно-ефрективним наслідком демократично-синергетичного тоdus vivendi.

Сучасне життя людства глобально й кардинально змінилося, і це відчувається, в першу чергу, завдяки появі інтернет-технологічного розповсюдження з майже світовою швидкістю пріоритетного та найвпливовішого чинника власне изивілізаційного процесу, а саме - ресурсу інформачійних знанъ. I саме тому сьогодні в світі виникла гостра й найактуальніша потреба проведення глобально-системних досліджень процесів світового і національного розвитку спільними міжнародними зусилями з формуванням адекватної методологіï.

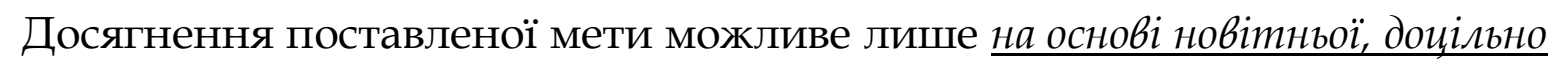
розробленої системно-інорормаційної методології, яка комплексно-структурно та иілісно-прочесуально враховує наӥвпливовіші чинники, що імперативно виявились в сфері трудової діяльності і сучасного загальносвітового розвитку.

\section{Глобально-синергетичний імператив демократизації як вияв цивілізаційного поступу}

\section{Одна голова - добре, а дві - краще (Народна мудрість)}

Нагадаємо ще раз, що базовим принципом тлумачення генези соціально-економічного добробуту $є$ глибока думка давньогрецького філософа Сократа: винахідницький геній народу - батько усякого багатства. Конкретизуючи, візьмемо до уваги той доленосний факт, що українське суспільство сьогодні складає головний іспит на свою життєздатність. Вочевидь, в тій чи іншій сфері життя виникають гострі кризові явища. Поглиблений погляд на ці явища надає можливість зрозуміти, що у нас 
фактично продовжується перманентна системна криза. Так, майже увесь життєвий простір охоплений виснажливою економічною скрутою. Особливо вражають явища дегуманізації $i$ деморалізачї суспільних відносин в небачених раніше масштабах. При цьому видається, що вже безповоротно втрачені такі вузлові цінності як довіра до влади, взаємодовіра й взаємоповага поміж людьми, природний потяг до творчої праці та відчуття відповідальності в політично-управлінській і соціально-економічній сферах. В окремих випадках можна просто зафіксувати брак здорового глузду, маніфестацію гострих психічних розладів. I тому зовсім не дивно, що при цьому навіть працездатна більшість населення країни опинилась в злиденному становищі, не кажучи вже про людей літнього віку та інвалідів. Продовжується сумнозвісний процес катастрофічного скорочення населення. I саме тому однією із найгостріших і найактуальніших проблем в Україні сьогодні вважаємо проблему подолання бідності, яка повязана 3 онтологічною та екзистениійною деімперіалізацією.

3 самого початку треба наголосити на головному: подолати бідність b украйнському суспільтві - це означае сорормувати украйнське суспільство всеєдиним за сутнісними параметрами, зробити ӥого більм духовним $i$ моральним, навчити иоого працювати приниипово краще, усвідомлено подолати негативні наслідки проімперського життя, але із збереженням иоого позитивних елементів.

Сьогоденний стан суспільства, в тому числі події революційного характеру, показують, що вже майже усі громадяни нашої держави здатні зрозуміти, що сподіватися можна лише на свої власні можливості і сили, на свій розум, на свою свідомість і волю. Звичайно, умови нашого життя тяжкі, але уже настав час добре усвідомити не лише одвічне прагнення до свободи, а й історично обумовлену, об'єктивну приреченість на національно відповідальний саморозвиток. А проблематика тут тісно пов'язана з проімперським минулим.

3 цього приводу слід наголосити, що як у найтяжчі години свого життя людина звертається до Бога, так і держава в стані небезпечної кризи звертається до народу - рятівної, об'єднуючої і оздоровлюючої сили. І коли народ $i$

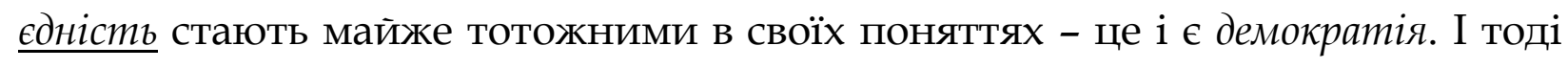
вже не знайдеться в світі сили, яка б змогла перевершити всепереможну владу єдиного у своїх прагненнях народу принципово покращити своє життя. Без усякого сумніву, цей насправді всесистемний принизип i має скласти основу нашої національної ідеї та підтвердити об'єктивний характер демократизації.

Де ж вихід сьогодні?

Як орієнтуватись в реальній псељдодемократичній плутанині?

Як пробудити та ефективно реалізувати глибинну, по-справжньому 
рятівну, суспільно всеоб'єднуючу та економічно оздоровлюючу фрункції демократіï?

Вихід є. Його світло вже давно проблискує у вирі пошуку шляхів прогресуючого розвитку, в боротьбі так званих ідеологій, у намаганнях людства пізнати глибинні механізми ефективної діяльості. Саме через розкриття цих механізмів і можна віднайти природно притаманне місие феномену демократіі та визначити ї фрундаментальну соиіальну сутність. Отже, тільки завдяки знанням об'єктивних закономірностей розвитку, сучасної діяљності та глобально ускладненої праці українське суспільство зможе починати подолання накопичених негативів та вийти на шлях антикризового, закономірно прогресуючого господарюљання, в першу чергу, заради задоволення найгостріших соціальних потреб. 3 цього приводу згадаймо основні причини загальносистемної кризи та бідності в Україні.

По-перше. Минулі десятиліття свідчать про те, що результати праці можуть бути не тільки позитивними. Хоч наш народ в цей час дуже тяжко працював, але він так і не побачив ні добробуту, ні демократії, ні духовно гідного життя. Найбільш видимими причинами цього були структурне та кадрово-управлінське спотворення економіки, пї дегуманізація й надмірна змілітаризованність (за радянської доби) всієї системи господарювання. Ці процеси фактично мають місце і сьогодні, тому що закономірно зберігають свій інериійно негативний вплив на всі без винятку сфери життя у так званому пострадянському просторі.

По-друге, в ті недалекі часи суспільство було дезорієнтоване тотально догматизованою ідеологією, тобто псевдознаннями на методологічнокониептуальному рівні. Хоч окремі напрями соціально-економічної методології при цьому, слід визнати, були однобічно, але поглиблено і навіть ретельно розроблені - наприклад, деякі приниипи системнодіалектичного аналізу суспільних процесів, але сьогодні, на превеликий жаль, ми є свідками повного фіаско глобального та найвпливовіного гуманітарного чинника господарювання. Отже, саме життя переконливо засвідчило, що усі системи з методологічно спотвореною орієнтацією неочікувано і начебто безпідставно розпадаються. Відтак, навіть тимчасовий локальний прогрес в mоталітарній державі закінчується врешті повним регресом.

По-третє, за минулих часів часто і безпідставно придушувалась навіть конструктивна критика, творча ініціатива та щиро усвідомлена праця людей. Саме така антидемократична політика надмірно, навіть катастрофічно, спотворила соціально-психологічну, економічну і духовнокультурну сфери українського суспільства. Ми сьогодні нагадуємо один великий музей тоталітаризму. 
Уважні роздуми над причинами цих подій схиляють нас до висновку, що за глибинною сутністю вони збігаються у феномені так званого «людського фрактору». I саме цей чинник, попри його глибинно впливову сутність і вирішальну роль в економіці, достатньою мірою не був врахований ідеологією «наукового ma реального соціалізму». А інерція кадрового корпусу реформаторського сьогодення на тлі загального методологічного дефічиту продовжує «вперто і дико» нагромаджувати сочіально-економічні негативи в нашій державі.

Таким чином, за умов наявності майже усіх необхідних для нормального розвитку ресурсів, включно 3 науково-технологічним потенціалом, катастрофічно скрутне становище України сьогодні можна пояснити лише методологічно-інформаційною кризою в сорері державного управління.

Отже, в загальному плані, можна сказати, що історичний процес національного державотворення в Україні тільки-но розпочався і гостро потребує суттєвого прискорення на основі відповідної методологіі. Та поки-що некомпетентні управлінці все далі заганяють в «глухий кут» головну рушійну силу сочіально-економічного процесу - чесну, прачездатну, активнотворчу ıюдину.

Неефективність дій наших новітніх управлінців обумовлена не лише фаховою некомпетентністю. Річ у тім, що зовсім не усвідомленими в українському суспільстві залишаються роль і питома вага показників морально-правового стану усього кадрового корпусу. I навіть якщо повністю ігнорувати наявність «зловмисних» намірів, неуспіхи наших державних діячів достатньою мірою можуть грунтуватися на інерційності «номенклатурного» менталітету, головними світоглядними принципами якого були і є фактично волюнтаристські «телефонне», «титульне» право, i навіть так зване право «недоторканності».

Отже, окрім певного дефіциту прямого досвіду самостійного державоуправління та відповідної освітньо-виховної підготовки, стан нашого кадрового корпусу характеризують низька правосвідомість, неповна компетентність, моральна неврівноваженість та відсутність здорового nатріотизму. А все це відповідно називається проімперським modus vivendi.

Таким чином, занепад інститутів суспільного саморегулювання та соціально-економічного поступу - науки, культури, права, етики та моралі, а також дефіцит науково-методологічної інформачій, особливо гостро відчутний на всесвітніх хвилях глобалізаційного розвитку, - ось справжня причина соціально й економічно загальмованого стану України сьогодні. Ефективними ліками тут можуть бути тільки влада i mворча працяя духовно 
об'єднаного на основі національних та загальнолюдських ијнностей народу, тобто сутнісно справжня, об'єктивно необхідна для успішного розвитку нашого суспільства ДЕМОКРАТІЯ.

Відомо, що одна голова добре, а дві - краще. Щоб добре зрозуміти глибинну соціально-економічну сутність феномена демократії, треба поглянути на неї з точки зору глобальної функиіональності, а не як на суто політичну категорію, тобто частину тієї чи іншої ідеології.

Спершу коротко оглянемо деякі сучасні світові реалії.

Яскравою закономірністю двадцятого століття виявилась історична недовготривалість тоталітарних та авторитарних, побто недемократичних режимів існування держав у різних регіонах світу (Італія, Іспанія, Німеччина, Чилі, Югославія, СРСР та інші). Звичайно, такі режими здатні за допомогою військової сили мобілізувати людей і швидко досягти зростання в сфері промисловості. Але це вже будуть режими надзвичайності, в об'єктивно методологічному плані розвитку далекі від оптимальності. Такі режими виснажують людей не лище фрізично, а й духовно. Психологія суспільного життя спотворюється при цьому аж до явищ «соиіального психозу», процеси розвитку стають однобокими, а демократичні процедури - формально одностайними, і посуті переходять у режим «лицемірства», «інтриганства» або «перешіптування».

Світовий досвід показує, що усі тоталітарні та авторитарні режими, хоч i недовго, але міцно тримались на військовіü силі, демагогічній заідеологізованості і терпінні народу. Услід за самоповаленням таких режимів кожна країна вибухово «демократизується» і починається важка й тривала, соціально та гуманітарно спрямована відбудова більш гармонійного плюралістичного суспільства.

Вище ми вже визначили, що економічно ефективною може бути тільки гуманітарно й соціально иілеспрямована праия. Але чим же забезпечується така цілеспрямованість? Знаючи, що мета в кожній системі праці, починаючи із загальнонаціональної до конкретної трудової, $є$ ідеальним інформаціитним відображенням бажаного результату, виваженого сочуіальими потребами й об'єктивними можливостями, можна зробити висновки про вирішальне економічне значення якісних науково-інорормаційних знань в життєво важливих процесах на сучасному глобалізаиійному етапі світового розвитку.

Глобальну, соціально та економічно значущу функиію інформаційного ресурсу сьогодні яскраво демонструють процеси майже суиільної глобалізації та вже фактично розпочатий перехід найбільш розвинених країн в стан так званих інформаційних суспільсть. Системний розгляд чинників соціальноекономічного зростання цих країн свідчить, що вони своїм успіхом 
завдячують, передусім, уважному ставленню до формування сучасного суспільного інформаційного простору, особливо до проблем інформатизаціӥ технологічно-виробничої сорери. Інтенсивне запозичення високотехнологічної інформації, наприклад Японією із США, забезпечило так зване «японське диво», а інтенсивні інформаційні потоки у Східно-Азійському регіоні зумовили прискорену появу нових індустріальних країн (Південна Корея, Таїланд, Сінгапур тощо). Сьогодні ці країни далекоглядно перйшли на шлях розвитку фундаментальної науки як основи прикладного соціальноеконономічного процесу, у поєднанні із рухом до демократичного mоdus vivendi.

Економісти всього світу сьогодні прямо чи опосередковано враховують інформаційний чинник в організації ефективного господарювання. Все частіше мова йде про «людсъкий капітал» та про наукоємні, отже інформаційно й інноваційно насичені технології. Цілком зрозуміло, що «людський капітал» можна набути лище за рахунок якісних інформаційних знань, отриманих сучасною наукою й розповсюджених через системи освіти та підготовки фахівців, загальні та галузеві інформфонди, комп'ютерні та інтернет-мережі.

Нові фундаментально-наукові інформаційні знання - відкриття або поняття про об'єктивні закономірності перебігу природних процесів цілеспрямовано трансформуються у прикладні, тобто перевіряються практичним використанням в активнотворчих соціально-економічних процесах: винахідництві, раціоналізації, проектуванні, освітньометодичних та організаційно-управлінських рішеннях, у виробництві. Тобто, окрім цілепокладальної функції, інформація як ідеально єдиний ресурс відіграє роль прогресотворчого фрактора, особливо в проиесах з високими показниками продуктивності праці та якості продукиії. Отже, це глобальна функція онтологічної інформатизацї як активнотворчої інноватизаціӥ життя, але вже на основі антиімперської глобально-системної методології [4].

Творча генерація та нагромадження функціонально необхідної для успішного соціально-економічного розвитку інформації - це справа всього народу. Режим творчої активності громадян нашого суспільства, в умовах системної кризи і проблематичного становлення державності, повинен бути значно більш інтенсивним навіть у порівнянні з творчою атмосферою в найрозвинутіших демократичних суспільствах сучасності. Отже, це яскравий приклад об'єктивної необхідності поступу суспільного самоуправління від проімперського до синергетичного демократичного modus vivendi.

Таким чином, проблеми розбудови усіх сфер всезагальної та локальної національної безпеки, а також антикризового підходу до процесів реформування економіки, необхідність прискореного виходу на 
конкурентноспроможний вектор господарювання в усіх галузях, тобто забезпечення стабільного економічного зростання, - отже прискореного подолання «режиму бідності», - все це інтегрально вирішується, насамперед, інтенсивним нагромадженням і зрештою використанням актуальних, ретельно перевірених на достовірність інорормаційних знань на основі творчої активності народу. Цей процес вважаємо ДЕМОКРАТІЕЮ.

Відтак, можемо зробити важливий висновок про те, що френомен демократії є соціально-економічним фрункиіоналом, а не тільки певною політичною чи ідеологічною самоцільною категорією. Головним своїм важелем вона спрямована на найшвидше досягнення і формування достовірних, mобто істинних інформаційних знань у всіх сферах, пов'язаних з соціальноекономічним життям, передусім та $b$ найбільшій мірі y сорері державного управління. Якби ці знання були відомі, до прикладу (не доведи Господи) одній людині, без урахування точок зору інших, то демократія була б, так би мовити, функціонально зайвою. Але це, звичайно, неможливо, саме тому, що демократія є природно необхідним чинником в системах суспільно ефрективної діяльності. Розуміння цього $є$ особливо важливим для суспільств, які долають кризу, бідність і намагаються стати на шлях стало прогресуючого розвитку.

Украйнське сочіально-економічне диво можливе, але за певних умов, які ми ж самі повинні створити. Тому, насамкінець розроблених автором та коротко викладених у цій роботі приниипово нових положень, приведемо головні глобально-системні висновки:

I. Глибинні функції народовладдя як феномену демократичного самоуправління в процесах побудови всебічно ефективного соціальноекономічного життя є природно закономірними, а тому об'єктивно необхідними в історичних процесах діяльності та розвитку на основі прогресотворчої науково-інформаційно-інтелектуальної здатності громадян кожної держави.

II. Свої соціально-економічні функції система народовладдя реалізує не безпосередньо, а через процеси творчої трудової активності, в тому числі в сферах делегування своїх представників до різних гілок влади державного управління, науково-виробничої та експертно-контрольної діяльності в усіх без винятку галузях господарювання.

III. Соціально-економічні системи, що базуються на принципі так званого імперського, а не демократичного, отже народно-творчого процесу, об'єктивно закономірно виявляються затухаючими, про що свідчить історія існування тоталітарних й авторитарних режимів, історія цивілізацій та великих імперій, історія побудови та функціонування суспільств сталого 
гармонійного розвитку.

IV. Як приклад, українське суспільство принципово може вийти 3 кризи, досягнути економічного успіху та подолати бідність лише за умов надання стимулів і свободи творчості кожному громадянинові, а також кардинального покращення стану в соціокультурній, науковоінформаційній, психо-духовній та морально-правовій сферах нашого суспільства. Це і буде безпосередній перехід суспільства до демократії.

$\mathrm{V}$. Доконечно рятівна функція та економічна ефективність суспільного самоуправління на основі mворчо ӥ демократично отриманих інформаційних знань може повністю проявитися лише у підприємницькій сфері, тобто в сферах великого (промислово-індустріального), середнього i малого бізнесу.

Масове підприємництво в Україні - це єдино живий, динамічний механізм найшвидшого виходу із стану ганебної бідності i досягнення рівня партнерських відносин в процесах економічного життя. Однак, функціонування даного механізму принципово можливе тільки на основі творчого інноваційного розвитку, тобто насамперед на фундаменті високих технологій та досконалих інформаційних знань про об'єктивні закономірності глобального соціально-економічного процесу, 3 урахуванням сучасних глобалізаційних хвиль і специфіки нашого національного буття. Мабуть слід також памятати про мінус «проімперського принципу життя з нашим універсальним правилом: я начальник - ти дурень, ти начальник - я дуренъ!».

\section{Гібридні війни як наслідок дефіциту демократії в науково-освітній cфepi}

Сучасний світовий розвиток яскраво демонструє не тільки прогресивну функиію френомену інформаціӥ в соціально-економічних і політичних процесах, а й надто великий негативний потенціал, в тому числі виявлений в поглибленні можливостей організації «народних» воєн. Сьогодні, просто перед нашими очима виникає «інформаційна війна», тобто розпочинається вже друга сbітова холодна війна, яка має реальну перспективу закінчитися гарячою фазою. Таким чином тут є досить гостра потреба більш глибоко поглянути в сутність взаємозв' язків і чинників глобального впливу на людське життя взагалі, особливо в сфері міжлюдських та міжнародних відносин, адже гарячі збройні протистояння та відносини ююдей завжди проімперські.

Кожна розмова про «вiūнy» на побутовому чи фаховому рівні, а тим 
більше на науково-методологічному, і навіть на суто теоретичному, засвідчує потенційну можливість або ж наявність кризового стану у певній сфрері нашого життя. Ми, наприклад, добре знаємо, що у сфері спорту, науки та й $b$ усіх процесах творчої діяьності людей природно панує змагальність та конкуренція, яка спочатку має здоровий і позитивний, навіть демократизаиійний характер, згодом набираючи більш-менш непомірного і взаємно войовничого потенціалу. Ми також уже свідомі того, що взаємна боротъба може переходити із латентної форми у відкриту вербальну дезорієнтаційну ворожнечу на усіх рівнях, починаючи із міжособистісних конфліктів і закінчуючи так званими ідеологічними війнами у світовому масмтабі.

Холодні це чи гарячі війни, їх виникнення і взаємозв' язки ми можемо певним чином зрозуміти тільки сутнісно та глибинно досліджуючи ці феномени 3 глобально-системної точки зору - найбільш сучасної в методологічному визначенні. Таке розуміння допоможе нам зрозуміти негативність тоталітаризму.

Отже, з позицій реального життя ми добре бачимо, що далеко не завжди суто конкурентний спосіб творчої діялності проходить кваліфіковано й компетентно та приносить лише очікувані позитивні результати. І цей факт важко спростувати, а ще важче науково відслідкувати та пояснити. Відтак, тут ми маємо повне право використати інноваційно розроблену нами глобально-системну методологію, яка адекватно враховує саме глобальну структуру фрундаментально найвпливовіших чинників світового процесу. Зрештою нами буде всебічно представлена ця структура відповідною монографією. В цій роботі лише коротко повторюємо, що в результаті наших сталих досліджень ця глобальна структура $b$ складі системно взаємодіючих найвпливовіших чинників: «людина, екосорера та інорорматизачія cbimy» чітко визначена з усіма взаємозв' язками та механізмами.

Скажемо, що найбільш сумними періодами усіх часів безумовно були міжнародні конфлікти із застосуванням різного виду зброї і технологій. Якщо ж глобально-системним чином розглядати проблематику холодних та гарячих війн, починаючи, зокрема, з періоду maк званих сbimobux воєн, то почнемо з того, що так названа перша сbітова війна вибухнула майже неочікувано, здавалось би, з якогось незначного приводу. А привід був насправді цілком глобальний - криза імперського modus vivendi.

Тут можна, звісно, віднайти політичні та юридичні аргументи щодо захисту взаємних національних інтересів. Але, як відомо, накопичувались ці конфлікти тривало, й не без спроби владнати їх вербально-дипломатичним, тобто трансінформаційним шляхом. Однак, уже навіть в процесі цих спроб ситуація дещо напружувалась, поступово переходячи в стан похолодшання 
стосунків поміж державами, які сповідували ті або інші ситуативні концептуальні підходи (політичні ідеологіï). В такому разі може бути доречним вислів - iстина на небесах, а сила b аргументах. Якщо сюди ще додати світогляд, рівень компетентності, здоров'я $i$ моралі політиків виконавчих суб'єктів у цих спробах, то якась міра похолодання та напруженість у міжнародних відносинах будуть достатніми для вибуху навіть світового збройного конфлікту.

Съогоденне життя ююдства видається надпроблематичним. І це головним чином тому, що надзвичайно інтенсивно виявили себе такі феномени як «інформаційний вибух» та інформаційно-технологічна революиія саме в сфері соціоекономічної діяльності та розвитку. I начебто сучасна наука високорозвинена, інформаційних ресурсів в світі чимало, а технологічна висота зашкалює, але рівень $i$ тиск проблем катастрофічно зростає. Про це переконливо свідчить не лише тематика Всесвітніх форумів 3 проблем глобального розвитку, а й виступи антиглобалістів, які по-своєму переймаються конкретикою регіонального, національного та особистісного життя як в економічному, так і в екологічному просторі. Саме тому ми, усі поінформовані оптимісти, так наполегливо говоримо про реальність i катастрофічність глобально-системної кризи трансінформаційної изивілізацї. Адже сучасне людство, треба прямо на це вказати, живе, вірніше існує, під постійною загрозою воєнного дамоклового меча.

Відтак, об'єктивно необхідна потреба життєзабезпечення людей та суспільства обумовлює не тільки їхню активну творчу працю - прямий трансінформаційний зи'язок глобальної системи, а й імперативно виявлену необхідність уважно відслідковувати соціально-економічну, екологічну та всезагальну безпекову ефективність своєї діяльності - зворотній трансінформаційний зb' язок изієї системи. Оскільки як прямим, так і зворотнім зв'язком мікропроцесуально (психоінформаційно) принципово може керувати мише ююдина, то доля усіх соціокультурних $і$ економічних процесів опиняється виключно в ї руках. Тобто, ефективність усякої людської діяльності залежить, насамперед, від наявності якісного інформаційного ресурсу, компетентності та здоров'я ююдини. Отже, проімперський modus vivendi - ие по-суті просто хвороба сучасного людства. А демократія потребує єднання всього народу.

Однак, життєва доля людства склалася таким чином, що, як показано вище, усі негаразди, особливо на сучасному етапі розвитку, не тільки продовжують «першогріховну» інерцію бутmя, а й додають новітні, навіть катастрофічні негаразди, та ще й у глобально-системному вимірі. Тому ми тут ще раз згадаємо про позитиви і негативи ефектів диференціаціï в усіх соціокультурних та економічних процесах. Відтак, за своєю глибинною 
сутністю та функцією цей важіль є неоднозначною транс-психо-інорормаційною силою щодо потреб й інтересів людей. Адже, изивілізаційний процес своєю передумовою потребує врахування не тільки стихійно природних закономірностей існування світу, а й специфріку природно закономірних потреб ююдини - істоти активно-розумно-соціальної. I тут є складнощі.

Додамо, що оскільки інформаційні чинники і психіка людини існують та фрункціонують безпосередньо, то теорія і практика в дослідженнях інформаційних процесів фактично співпадають. Такий тісний діалектичний взаємозв'язок ицих чинників в умовах недостатньої правосвідомості громадян та аморальності b суспільстві надає їм можливості не тільки зловживати інфрормаційними ресурсами, а й небезпечно маніпулювати загальним соціальнопсихологічним простором. А перманентний процес віртуалізації життя, тобто інтенсивний процес відчуження людей від живої реальності, відтак від ПРИРОДИ та достовірної інорормації, може призвести, та вже й призводить, хоч і дещо неявно, до катастрофічної кризи глобально-системного виміру.

Нам треба дуже добре усвідомити, що ІНФОРМАЦЯ - наймогутніший ресурс изивілізаційного поступу людства і найнебезпечніша зброя ХХІ століття.

Відтак найоловніший висновок нашого усвідомлення, представленого $b$ цій роботі, полягає $b$ розумінні об'єктивно необхідного поступу сучасного людства від суто проімперсъкого до демократичного тодиs vіvепdi шляхом суттєвого удосконалення організації науково-освітньовинахідницької сорери як ісрархічно первинного чинника здобутку $і$ розповсюдження якісних інформаційних знань - найактуальнішого й найвпливовішого пріоритетного ресурсу соціально-економічного розвитку ма циивілізаційного поступу.

\section{ЛITEPАТУРА}

1. Скаленко О. К. Ключові виклики і алгоритми сучасного світового розвитку: історичний матеріалізм чи глобальносистемна методологія? // Суспільнополітичні процеси. 2016. Українська академія політичних наук. Вип. 4.

2. Скаленко О. К. Глобальна науково-інформаційна основа постіндустріального розвитку. Доповідъ МА «Римський клуб-Украӥна». К.: ICEMB НАНУ, 1994.

3. Скаленко О. К. Глобальні резерви поступу: інформація+інтелект+інновації. К.: Основи, 2000.

4. Скаленко О. К. Глобалістика трансінформаційної цивілізації. Київ, 2018.

5. Вернадский В. И. О науке. Том 1. Дубно: «Феникс», 1997.

6. Бард А., Зодерквист Я. Нетократия. СПб.: Стокгольмская школа экономики, 2004.

7. Glen T. Martin. Ascent to Freedom: Practical \& Philosophical Foundations of Democratic World Law. Radford, 2008. 
Dr. Prof. Oleksii Skalenko (Kyiv, Ukraine)

GLOBAL \& SYSTEMIC DIMENSIONS OF THE WORLD HISTORICAL PROCESS: THE PATH FROM IMPERIAL TO DEMOCRATIC MODUS VIVENDI

This work conceptually presents the author's scientific "roude map" of the movement of the historical process on the path from "proimperial to democratic mode of vivendi" based on an innovative global-system approach. The phenomenal realities and trends of the world in XX-XXI centuries, in which, along with the inertia of imperial thinking, intensified the forces of democratization of life, were recorded. For example, the processes of state-building in Ukraine and the launch of so-named hybrid wars are taken. The main reason for the intensification of the democratization of the world is the critical mass of information knowledge in the world.

Keywords: Global-Systemic Approach, Empire, Modus Vivendi, Democracy, Informatization, Crizis, Civilization, Deficit.

Алексей Скаленко (Киев, Украина)

\section{ГЛОБАЛЬНОСИСТЕМНЫЕ ИЗМЕРЕНИЯ ВСЕМИРНО-ИСТОРИЧЕСКОГО ПРОЦЕССА: ПУТЬ ОТ ИМПЕРСКОГО К ДЕМОКРАТИЧЕСКОМУ МODUS VIVENDI}

В данной работе концептуально представлена авторская научная «карта движения» исторического процесса по пути от «проимперского к демократическому модусу вивенди», основанная на инновационном глобальносистемном подходе. Автором зафиксированы феноменальные реалии и тенденции мира в XX-XXI веках, в которых наряду с инерцией имперского мышления активизировались все силы демократизации жизни. Например, предпринимаются процессы государственного строительства в Украине и запуска так называемых гибридных войн. Основной причиной активизации процесса демократизации в мире является критическая масса информационных знаний.

Ключевые слова: глобально-системный подход, империя, Modus Vivendi, демократия, информатизация, кризис, цивилизация, дефицит.

Олексій Скаленко (Київ, Україна)

ГЛОБАЛЬНОСИСТЕМНІ ВИМІРИ ВСЕСВІТНЬО-ІСТОРИЧНОГО ПРОЦЕСУ: ШЛЯХ ВІД ІМПЕРСЬКОГО ДО ДЕМОКРАТИЧНОГО МОDUS VIVENDI

У даній роботі концептуально представлена авторська наукова «карта руху» історичного процесу від «проімперського до демократичного модусу вівенді», заснована на інноваційному глобально-системному підході. Автором зафіксовані феноменологічні реалії та тенденції соціально-економічного поступу світу протягом XX-XXI століть, в яких поряд 3 інерцією імперського мислення активізувалися всі сили демократизації суспільного життя. Наприклад, запущені процеси державного будівництва в Україні, розвивається практика так званих 
гібридних воєн. Основною причиною активізації процесу демократизації в світі, на думку автора, є критична маса накопичених інформаційних знань.

Ключові слова: глобально-системний підхід, імперія, Modus Vivendi, демократія, інформатизація, криза, цивілізація, дефіцит.

* Скаленко Олексій Карпович - провідний науковий співробітник відділу теорії та методології всесвітньої історії Державної установи «Інститут всесвітньої історії» Національної академії наук України, академік Міжнародної академії інформатизації при ООН, президент Міжнародного благодійного фонду «Сднання». E-mail: icf_unity@ukr.net. 